I Federal University of Rio de Janeiro (UFRJ),

Department of Anthropology, Rio de Janeiro, RJ, Brazil

elagrour963@gmail.com

Els Lagrou'

\title{
COPERNICUS IN THE AMAZON: ONTOLOGICAL TURNINGS FROM THE PERSPECTIVE OF AMERINDIAN ETHNOLOGIES
}

\section{INTRODUCTION: THE ANTHROPOCENE AND THE AMERINDIANS}

This article originates from a paper presented at the Boas Seminar at Columbia University, New York, in May of 2016. The circumstances in which the argument was presented are so intrinsically bound up with how I address the recent debates concerning the intellectual trend in anthropology that is known as 'the ontological turn', that I have decided to preserve, in this published version, those signposts that situate the author and her audience. It was the challenge of presenting a line of thought with which, in my view, my very specialized audience of eminent anthropologists was relatively unfamiliar, that demanded this exercise in conceptual archaeology. Had I approached the debate from the standpoint of Amerindian ethnology, many of the presuppositions made explicit in this article would have remained implicit. When teaching about the topic in Brazil, I came to realise that contextualising the history of a concept in this way can be useful for students as well, especially for those unfamiliar with Amerindian ethnology.

A conversation with Marilyn Ivy ${ }^{\mathrm{I}}$ on the role of Amerindian ethnology in contemporary anthropological debates prompted an invitation to tackle this topic from my perspective, which is that of a European doing anthropology in Brazil with Amerindian peoples. Once I began to think seriously about it, I realised that this was not at all an obvious task. I had to tackle a complex question, riddled with diplomatic risks. First, everything about the phenomenon is open 
to discussion: from the term 'ontological' itself, through the differential uses and theoretical filiations it invokes, to the matter of whether we are dealing with a singular turn or several turnings, and the relation of this turn to previous theoretical turnings in the discipline. Quite a lot has been written and said about the topic over the past ten years. ${ }^{2}$ In the United States, for example, the ontological turn gained academic visibility during the 20I 3 American Anthropological Association annual meeting in Chicago, with a panel on the topic and its relation to politics proposed by Martin Holbraad, Axel Pedersen and Eduardo Viveiros de Castro. Elizabeth Povinelli ${ }^{3}$ was among the invited discussants.

We are all undeniably enmeshed in the same vast web of Late Capitalism that infiltrates the most remote areas and aspects of our lives with its commodities, toxic substances, viruses, mosquitos and epidemics, and its implacable logic of exploitation of the seas, the soil, the territory. In reaction to this recklessness, a passive Nature suddenly became Gaia, a 'living being', 'unpredictable and indifferent' as Stengers (20I0) would have it. All this affects, most of all, the minorities and 'the otherwise' (Povinelli, 20I6), who become resignified as the poor in need of commodities and assistance. These same people, however, have the practical - but above all relational - knowledge of living otherwise, and can show us lines of flight out of the vicious circle of blind developmentalism.

The environmental crisis is now so evident and pressing that the problems caused by the anthropocene - the era in history when humanity began to dominate, rather than coexist with, the so-called 'natural world' (Sayre, 20I 2: 58) - demand an urgent and comprehensive rethinking of our categories and the relations between nature and culture, thought and being, human and world. The recent interest in Amerindian ontologies in the fields of the Arts and Sciences should be seen in light of this. ${ }^{4}$ By co-evolving with, rather than destroying, the animated environment of other beings that surround and inhabit them, these collectives reveal different ways of 'being-with', just as their praxis exhibits proof of eminently relational worlds and ontologies.

The substitution of relational ontologies by the opposition between 'subject' and 'object' enabled the Modernist and Capitalist enterprise to invent its world-conquering machinery, trapping in its gears even the most resilient minorities surviving at its margins. The ontologies of these minorities speak a language that resonates with what contemporary philosophers of science are looking for. Thus, in her videoconference for the "Thousand Names of Gaia" Colloquium, Donna Haraway argued for a renewed awareness of how all beings, including humans, are composed of other beings and enmeshed in a dense web of becoming-along-with. Instead of inter-relationality, we are dealing with an intra-relationality; we are entities composed of relations, cut across by other agencies and inhabited by different subjectivities. ${ }^{5}$ We are multiple and dividual rather than individual (Strathern, I988); we are fractals (Wagner, I99I; 
Kelly, 200I). What these new ideas can teach us are not all that different from what we can learn from native Amerindian philosophies.

Haraway argues that "we need to look for allies also in unlikely places, look for alignments in dreadful zones [...] we are inhabiting the belly of the monster the way the Amerindians inhabit the belly of the monster and form unlikely alliances and become someone they had no intention of becoming". This situation calls for strategies of guerrilla warfare. "The notion of an entity plus an environment is what we can't think anymore... We have what biologists call holobionts, the collection of entities taken together in their relationality that construct a good enough one to get through the day". We need to learn from the Japanese how to use the force of the other to win, she argues. This is certainly an art Brazilians are very good at, from the afro-Brazilian capoeira to the xondaro of the Guarani (Bregalda, 2017).

The hubris of Modernist ontology needs to be corrected by taking conscience of the processes of sympoiesis, of our creative becoming in symbiosis with other species. Our origin myth of the world also needs to be revised, argues Haraway (20I4), since the world as we know it today is the failed outcome of a cosmic act of mutual cannibalism: two bacteria trying to devour each other could not digest one another, and as a result we have the contemporary cell, more complex than the original one.

The ontogeny of the Piaroa, a people of the Venezuelan rainforest, rehearses a similar story about the origin of the world as the result of a cannibalistic battle between two antagonistic forces, brothers-in-law that fight until they devour each other. In this way, all of the differences in the world gained form during a mythic time of cumulative history and extreme creativity. This extremely creative power, however, poisoned the life of the senses of the beings on earth. To make life on earth possible, the Piaroa adopted an ethics and aesthetics of conservation instead of accumulation, a history that works to keep things in place and avoid the return of uncontrolled creative forces and their autodestructive and poisonous potential (Overing, I986b, I989, I990).

The origin myth of the Yanomami similarly meditates on the dangers of uncontrolled productive desires that give rise to people with 'minds planted in merchandise'. Minerals were planted by Omama, the creator god. Like the bones of a skeleton, they sustain the earth. The peccary people, as the Yanomami call the gold miners and their digging equipment, put this delicate geological construction in danger, releasing the lethal smoke of metal that carries the deadly epidemics that afflict the inhabitants of the forest and their shamans. Through their songs and dances, shamans keep the xapiri image-beings that animate the forest alive. When the last shaman dies, the xapiri will become enraged and cause the sky to fall upon the earth (Kopenawa \& Albert, 2010).

Davi Kopenawa's story about the dangers of the end of the world is a good example of what Elizabeth Povinelli calls a 'geontology' and the cosmopo- 
litical agencies necessary to keep geological formations in place. Different geontologies think differently the relation between life and nonlife, such as rocks, stones, creeks, and the desert. By emphasising nonlife, Povinelli points toward the limits of an evident vitalist tendency in the literature on different relational ontologies, which ponder life in terms of a constant process of engendering, being born, growing and dying. "For the animist everything has life", says Povinelli in her interview. But, for the Aborigines, the landscape of the Australian desert is the outcome of events and acts that happened to the ancestors in the past; though it is nonlife or landscape, it nonetheless needs a relational network of reflection and intentional actions, of strategies that enable the rocks or creeks to continue to exist. "I am the analytic subject asking, 'how, in the world I am in, do I keep myself in place?' and that is absolutely not the typical anthropological concept of the other" (Povinelli, 20I4).

As an alternative, Povinelli proposes the concept of the 'otherwise'. "The otherwise is that which is within something and causes that thing to shake and the whole system to turn into something else" (Povinelli, 2014). Instead of the 'other as other' in opposition to a 'we', framing the otherwise as being internal to an 'us' enables minorities to act within majorities and to thereby transform them. This idea comes surprisingly close to the Amerindian definition of otherness, whereby 'self' and 'other' are intrinsically intertwined and traversed by processes of other-self-becoming or becoming-otherwise (Lagrou, I 998). Every person is the result of a complex bricolage of different agencies acting together, in such a way that a collectivity of beings or their habitat can remain in continuity with what it was before, without thus negating the incidence of forces that change it. 'Nature' for Amerindians is constant variation; to be alive is to improvise with the means at hand in the creative invention of everyday life (Wagner, I975).

An eloquent example of this mode of being are the Pirahã, who always experiment, producing miniatures that seek to emulate or look like other things and beings. They thereby follow the example of Igagai, the creator, who produced the animals, moulding them from mud and improvising in the process, working through resemblances and differences. The world is not only composed of successful experiments, but also of predatory events, failed cannibalizations. New human bodies, for instance, are conceived by a fright caused in a woman by an unsuccessful predatory act. And a new image-being6, 'spirit' or 'god', abaisi, is born when a human body suffers an accident caused by another agent and liberates a double as a result. The world is in a constant process of creating forms and images in interaction with and reaction to each other (Gonçalves, 200I).

\section{THE ARCHAEOLOGY OF A CONCEPT}

Until recently, for my ethnologist colleagues in Brazil and I, the ontological turn had been the given Ground against which we have been shaping our Figures. Each one of us has been searching for an idiom that comes as close as possible to 
how native collectives conceive their relations to the world and its beings in a constant process of becoming. We have been exploring all of these possible transformations as if following the chromatic variations of Amerindian mythologies and socialities themselves.?

Born of the theoretical efforts of pioneers such as Claude Lévi-Strauss and Pierre Clastres, Amerindian ethnology has always had a vocation for changing the course of the discipline and how we think about humanity. When they chose the Americas as the destiny of their travels, Lévi-Strauss and Clastres were already familiar with the writings of the first chroniclers and the critical reflections they provoked in La Boétie ${ }^{8}$ and Montaigne. It should hence come as no surprise that their anthropology was profoundly affected by the way Amerindian collectives themselves think and act. Some say Lévi-Strauss' (I99I) structuralism, and his theory of 'dualism in a state of perpetual disequilibrium', would have been impossible if not for his immersion in indigenous thought as evident in the Mythologiques (Taylor, 20I I).

In the I970s, in his important book Society against the State, Clastres made explicit his ambition to provoke a 'Copernican revolution' in the political thought of the metropolis: instead of thinking of the native peoples of the Americas along with the sixteenth century chroniclers, who saw them as peoples 'without faith, without law, and without king' - that is as people who lacked political organization, or society tout court, since they were not organized through the State-Clastres sought to turn political philosophy on its head. We know the influence that this idea had on the writings of Deleuze and Guattari (I987):

A Copernican revolution is at stake, in the sense that in some respects, ethnology until now has let primitive cultures revolve around Western civilization in a centripetal motion, so to speak. Political anthropology appears to have made it abundantly clear that a complete reversal of perspectives is necessary. Political anthropology encounters a limit that is not so much a property of primitive societies as it is something carried within anthropology itself, the limitation of the West itself, whose seal is still engraved upon it. In order to escape the attraction of its native earth [...] reflection on power must effect a 'heliocentric' conversion: it will then perhaps succeed in better understanding the world of others, and consequently our own.

The path of its conversio'n is shown, moreover, by a contemporary mind that has been able to take seriously that of Savages: the work of Claude Levi-Strauss [...] It is time to change suns, time to move on (Deleuze \& Guattari, I987: 25-26)

Almost ten years ago, in a comparative essay on Amerindian arts and artefacts, inspired by Gell's Art and agency, by Clastres' and Lévi-Strauss's contributions to a non-representationalist approach to images and artefacts, by Viveiros de Castro's perspectivism, as well as by the writings of Joanna Overing, I wrote on art as a way of giving form to thought, of producing life and bodies. Motivated by the image of the inversion of perspectives, I followed Clastres in his use of the Copernican metaphor: 
In this book we explored the theoretical consequences of an ethnological perspective on Amerindian arts. The specificity of this perspective resides in not taking as a point of reference any of the previously available definitions of art, be these aesthetic, interpretive or institutional. We thus envisage a Copernican revolution for art, equivalent to the one effected by Pierre Clastres for politics [...] By looking at our own society with Amerindian collectives as a reference point, the criteria of evaluation necessarily change.

[...] If we look at art as an art of building worlds, and no longer as a phenomenon to be distinguished from the artefact - as a sphere of practice associated with the extraordinary, that needs to be kept apart from the everyday in order to keep its sacredness - the cognitive relation is inverted. This figure and ground reversal reveals a new figure, a new ground. Nothing in the form, or sense or context of things predisposes them to be classified as art or not art. In this way, works of art can be human bodies sculpted by ritual intervention, through ritual song and medicinal baths, dieting and a more properly physical moulding (which may consist of different techniques of producing a body/person deemed 'beautiful'; aesthetics is ethical uprightness).

The result is that the body becomes a conceptual artefact and the artefact an almost-body, and that the trajectories of bodies and artefacts increasingly converge. Another result is that functionality and contemplation become inseparable; aesthetic efficacy results from the capacity of an image to act upon and thus create and transform the world. If art, our own and that of others, continues to fascinate, it is because we can never cease to dream up the possibility of creating new worlds. This possibility of coexistence and superimposition of different worlds which are not mutually exclusive is a lesson we have yet to learn from Amerindian art (Lagrou, 2014:I04-I05).

Copernicus again emerges as a powerful image in the work of Martin Holbraad, who, along with the co-editors of the volume Thinking through things, is generally taken to have been among the first anthropologists to use the label 'the ontological turn' for what they then called 'a quiet revolution [going on] in anthropology'. Among the anthropologists who influenced the turn, they mention "not only Latour, but also Alfred Gell, Marilyn Strathern, Eduardo Viveiros de Castro and Roy Wagner" (Henare, Holbraad \& Wastell, 2007: 8).

In 20I6, while presenting the argument which, later that year, would be published as The ontological turn: an anthropological exposition, Martin Holbraad reduced the number of thinkers responsible for what he calls 'the radicalization of anthropological inquiry' to three, each one representing one of the principal intellectual traditions of the discipline: Roy Wagner, representing the Americans; Marilyn Strathern the British; and Viveiros de Castro, the French. This last characterization is somewhat ironic, since Viveiros de Castro, who is Brazilian, proposes that the turn's ambition must be to “invert, turn, the relation between ethnographic materials and analytical resources on its head. Ethnography thus becomes the source of our concepts, not the object" (Holbraad, 2016).

The decolonization of anthropology had been on the agenda of Amerindian ethnology for some time. As early as I977, Joanna Overing called on par- 
ticipants of a symposium on Amazonia to think with the natives in order to discover concepts that would permit us to come closer to the way they think, thereby avoiding concepts imported from other ethnographic regions. Overing's papers during the I980 frequently use as a subtitle the idea of taking seriously the existence and creation of 'multiple worlds' (Overing, I 990). ${ }^{9}$ Viveiros de Castro's article, "The relative native”, written a few years after his important article on perspectivism, is a powerful formulation of this political project that takes native thought seriously, so far as our conceptual language permits. The article thus functions as a sort of methodological manual for the new anthropology envisioned. This is also why the concept of controlled equivocation is crucial here. Viveiros de Castro (2004, 2013) talks of anthropology as comparative ontography, the true point of view being that of immanence.

After the 'linguistic turn', the 'interpretive turn', the 'reflexive turn', and the 'epistemological turn', all of which have affected anthropology as critical reflections on our method of inquiry and the language we use to talk about others, we now have an 'ontological turn', or turnings, that has as its most characteristic mission the attempt to eschew the problems of representation. I cite Viveiros de Castro (2014: 43) from the introduction to his Cannibal metaphysics:

The descriptions of the conditions of the ontological self-determination of the collectives studied will absolutely prevail over the reductions of human (and nonhuman) thought to a dispositive of recognition: classification, predication, judgment and representation.

But let us return to ethnographic soil. In Brazil, anthropologists specialising in the study of indigenous peoples tend to follow two distinct theoretical orientations: the 'ethnologists' study otherness and indigenous transformations, including those resulting from the presence of different kinds of representatives of western society and capitalism in their territory, from the point of view of native conceptualizations; while the 'inter-ethnic relations' group studies indigenous collectives and their varied involvements with the nation state from the perspective of the different ways in which extractive activities, missionaries and the presence of the nation state impinge upon indigenous groups.

Both approaches can be considered complementary. It should be stressed that the anthropologists who specialise in the study of the interface between the nation state and Indigenous peoples and those that study the Indigenous collectives ethnologically are equally involved in sustained and remarkably far-reaching political engagements for the protection of indigenous rights. It is an important point to be made that, historically, in Brazil, native peoples have been able to count on anthropologists for the protection of their rights, and that this fact is recognized by native peoples themselves. Thus, in the I970s and early I980s, during the military dictatorship, Manuela Carneiro da Cunha, Eduardo Viveiros de Castro, Lux Vidal and their students were founding members of the first NGO dedicated to the protection of indigenous rights (the Co- 
missão Pró-Índio). Manuela Carneiro da Cunha played a crucial role in the revision and redaction of the statute of indigenous rights in the Constitution of 1988 , which guaranteed the rights of Indigenous collectives to their lands during the re-democratization of Brazil. ${ }^{\text {}} \circ$

As pertains to the impact of the ontological turn on anthropology at large, the traditional isolation of Brazilian ethnology from wider theoretical debates has started to change, as an increasing number of non-ethnologists have shown interest in 'reverse' or 'symmetrical anthropology' and in the methodological possibilities contained in the writings of authors such as Roy Wagner, Bruno Latour, Marilyn Strathern, Tim Ingold, Philippe Descola and Eduardo Viveiros de Castro. All these authors are regularly taught in courses that are not specifically about native Amazonian peoples. ${ }^{\text {II }}$

It thus appears to me that one of the effects of the so-called ontological turn is that this discreet isolation of specialists writing about collectives living at the margins of late capitalism, in Amazonia, Melanesia, New Guinea and Australia, has come to an end. For me, personally, being invited to speak on the ontological turn to a broad audience presented me with the challenge of turning the Ground against which 'we' (Brazilian ethnologists as a collective) traditionally invent our figures into the Figure of reflection itself, and to thereby make the Ground explicit. This can only be done from my own point of view, as someone engaged in the Amazonian ethnological debate; but also from an anchoring in the non-representationalist debate in the anthropology of art - a debate that has been going on, one could say, since the publication of Boas' Primitive art, and in which Lévi-Strauss, in dialogue with his surrealist friends in New York, played an important part (Clifford, I98I, I988).

We ethnologists know fully well that our Northern colleagues, as well as our non-ethnologist colleagues at home, used to think that the ethnological style of doing anthropology was 'traditional', and that this ambition of getting close to the conceptual skin of the natives (in the Malinowskian sense) was long due a thorough deconstruction. But it appears to me that the ontological turn is a different answer to the same problem of the crisis of representation in anthropology, and that this new conceptual construct would have been impossible had the field not been cleared by the deconstruction of the vices of representation. Before the invention of the label 'ontological turn', some called this movement 'post-structuralism'; others called it 'post-post-modernism', although we know, to quote Latour, that "we have never been modern" anyway (Latour, I99I). Those who had until recently been labelled as traditional and/or structuralist, "people who still read Lévi-Strauss", have now been redefined as part of a new turn, a new salvation for anthropology. To cite Marshall Sahlins (2013: xi) in the preface to Descola's Beyond nature and culture: ruptive effects of global capitalism on the cultural integrity of the peoples it 
traditionally studied, along came this remarkable work by Philippe Descola offering a novel theoretical armature of ontological dimensions and universal proportions for knowing the varieties of the human condition.

Descola's is one of the versions of the ontological, but certainly not the only one. My short archaeology of this ontological turning of the anthropological language is rooted in the perspective of Amerindian ethnologies; as I have already set out, it is completely informed by this very specific and situated point of view. Let me start, then, with my colleague from Rio, Tânia Stolze Lima. She poses the question of how to think with the Yudjá and with LéviStrauss in order to overcome apparent paradoxes in the language of both, related to the concepts of 'human' and 'animal'. Instead of positing distinct classes of beings, she proposes to think through relations of opposition (by definition themselves unstable) between human and nonhuman, animal and nonanimal, spirit and nonspirit.

Though it perceives itself as human, the capuchin monkey is an animal for the Yudjá. The night monkey, in contrast, is more spirit than animal. The difference between to be and to have a spirit or soul is crucial for the Yudjá, as indeed it is for the Huni Kuin (Cashinahua). But the Yudjá go one step further: in the diffuse or contiguous zone of animals that can be human, and humans and animals that can be spirits, the humans possess the moral privilege of reflexivity. Only humans know that the world is characterized by the duplicity of all beings, so that the subject never knows its double. This is an interesting psychological theory, and the Yudjá theory of subjectification contains an important asymmetry:

Human wisdom consists of what we call reflexivity: those who are alive know that the dead consider tucunare fish to be corpses; but the dead do not know that this is known with respect to them, nor do they know that those who are alive consider tucunaré fish as such. This relative unreason, that is, this incapacity to put themselves in perspective, characterizes the existence of animals as well as our own onirical existence [...] This is the sort of moral relation the Yudjá have with the animals (Lima, I999a: Io; translation by the author).

This 'non-reciprocity of perspectives', as Gonçalves (200I) called it when referring to a similar phenomenon among the Pirahã, differs from the more widespread character of perspectivism, where the symmetrically inverse quality of the relations between the human and nonhuman point of view is emphasized. An example of this last logic can be found among the Wari described by Vilaça (I992) and Conklin (200I). Here, when a subject, the hunter, imposes his point of view upon another, the point of view of the Other disappears: as game, the Other becomes the object of the action of a Subject, in an agent/patient inversion similar to that proposed by Alfred Gell for the agency of objects in his Art and agency. Accordingly, the self-designation of the Wari means 'predator'.

The non-reciprocity of perspectives is not absent from the comparative model proposed by Viveiros de Castro. He mentions it in the context of encoun- 
ters with spirit beings, dangerous encounters in which to be addressed as 'human' by a nonhuman triggers processes of metamorphosis. However, its detailed ethnographic description - as I will show below - traces interesting lines of flight. The non-reciprocity of perspectives is, precisely, the characteristic chosen by Descola (2013: I40) in order to frame perspectivism as a particular and restricted case of Animism, as he explains in his book Beyond nature and culture.

In 'standard' animism, humans maintain that nonhumans perceive themselves as humans because, despite their different forms, they all possess similar interiorities (souls, subjectivities, intentionalities, enunciative positions). To this, perspectivism appends an additional clause: humans claim that nonhumans see humans not as humans but as nonhumans (animal predators or spirits) [...] But this crossed inversion of the two points of view, which is the defining characteristic of perspectivism, is by no means attested by all animist systems.

Viveiros de Castro credits Lima with stressing that 'a point of view' for the Yudjá is not to be confounded with our classical western cultural relativism. ${ }^{12}$ This was an important step in the direction of solving a recurring problem with expressions such as 'perspectival quality' and 'perspectival relativity', used by Kaj Århem (I990) and Andrew Gray (I996), respectively, to draw attention to this very common phenomenon in Amerindian conceptualisations of human/animal relations.

Viveiros de Castro's demonstration of how perspectivism differs from the relativism of different points of view on a common world has been his greatest contribution to the ongoing debate on the place of the Nature/Culture divide in Amerindian ethnology. His argument can be summarized as follows: if cultural relativism posits the existence of a multiplicity of cultures professing different points of view on a single nature (the well-known multiculturalism), Amerindian perspectivism posits the existence of a multiplicity of natures corresponding to one single point of view, one single culture (that is, a multinaturalism). The point of view creates the subject, not the object, as is the case in social constructivism. To accede to a point of view is to be a subject and every subject conceives of him or herself under the general form of humanity - that is, as a being marked by intentionality, consciousness, perception and conception. When nonhumans are among their peers, they are systematically represented as doing exactly what humans do: hunting, cooking, sleeping in hammocks, marrying one's cross-cousin, going to hunt with one's brother in law etc. The description of their lifeways follows the characteristics of the daily life of the group telling the myth.

"'Culture' would be the auto-anthropological schema [...] of the first-person pronouns 'I' or 'me'” (Viveiros de Castro, 2012: I06). In this sense, the widespread use of self-designations meaning 'people' by Amerindians is crucial to Viveiros de Castro's argument. It proves that Amerindian anthropomorphism should not be confused with anthropocentrism. Thus, the Cashinahua (an originally pejorative name meaning 'bat people' given to them by their neighbours, 
who used to be their enemies), refer to themselves as huni kuin, 'real people'; or, in a more accurate translation, 'people properly speaking', or 'people like us'. Instead of a substantive quality, these self-designations share a pronominal unity. Thus huni kuin means 'we', displaying all of the contextual amplitude of similar pronominal categories. In its more restricted acceptation, it can be applied to those speaking the same language and living together; in its wider sense, it can refer to 'all indigenous people living in the forest'. The Cashinahua are thus no different from their neighbours, the Ashaninka/Campa and Piro/Yine. By declaring that they want to be called huni kuin by others (as they indeed do, in the newly defined political context of inter-ethnic relations), they insist on having these others call them: 'we, the people' (Viveiros de Castro, 20 I2, cites Gow, 200 I for the Piro).

What differs (and difference is crucial here) for the Amerindian ontologies under discussion, is the body "as an assemblage of affects or ways of being that constitute a habitus" (Viveiros de Castro, 20I 2: I I3). The fact that different beings possess different bodies, with different affects, inclinations and capacities, accounts for the difference of perspectives when species meet. Multinaturalism is therefore not so much a theory that postulates 'a variety of natures' but rather one that considers 'variation as nature' (Viveiros de Castro, 20I4: 74; Ochoa Gautier, 2016: I09). To use the most well known example, referred to time and again in the literature: when a human encounters a jaguar devouring his game, the blood he sees is seen by the jaguar as maize beer.

The mismatch of perspectives is also characteristic of relations between the living and the dead, since they too have different bodies. For the Huni Kuin, the dead become Inka cannibal gods. In order to conceal one's humanity when visiting the village of the dead, one has to behave like they do. This involves eating the lice in the hair of their Inka hosts. But the lice look like big beetles to the living. When the female visitor expresses her repugnance at eating beetles, the Inka realize that she is human. They kill and eat her. It is what you do rather than what you look like that reveals who you are; that is, to which collective your body belongs.

This new way of thinking the relation between nature and culture in ethnology is reminiscent of the synthesis proposed by Marilyn Strathern for Melanesia in the Gender of the gift, which reflected the regional focus on the themes of gender and systems of gift exchange. In Melanesia, the concepts of person and thing were redefined by indigenous ways of thinking, while in Amazonia the predominant theme has been the relation between humans and nonhumans, nature and culture. The similarities between Strathern's gift/commodity opposition and Viveiros de Castro's multinaturalism/multiculturalism opposition have been recognized by Viveiros de Castro (2012) in a series of lectures

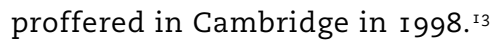

The rethinking of the nature/culture binary was, in fact, a collective enterprise, involving ethnologists trying to come as close as possible to the way Amer- 
indians think (Overing, I977). In the I970s and I980s, American ethnologists such as Joanna Overing and Christopher Crocker criticized Lévi-Strauss for over-stressing the metaphorical and totemic logic of indigenous thought. They drew attention to the need to take into account the metonymical aspects of enunciations such as the renowned Bororo claim that "my brother is a parrot" (Crocker, I977). Feminist thought also had an impact on the nature/culture debate, as evident in Overing's critique of Lévi-Strauss's association of women with nature and her demonstration of the fact that nothing in Amerindian thought about procreation can be considered given or thoughtless; for the Piaroa of Venezuela, conception and gestation, for example, are products of women's thoughts (Overing, I986a).

Based on extended fieldwork among the Achuar that resulted in his book La nature domestique (I986), Descola has sought to overcome the limits of the opposition between Nature and Culture inherited from Lévi-Strauss. The first article in which he reintroduces the concept of animism was published in 1992. In this article, Descola opposes two schemes for the objectification of nature that he, at the time, termed 'animistic' and 'totemic'. In his next article on the topic, Descola (I996) continued to use Lévi-Strauss's definition of totemism as a 'logic of classification'. This changed radically in his 2005 book, where the logic of continuity between species and clans linked by Dreamings and common ancestors is taken into account, resulting in a redefinition of totemism as a system of continuity of physicality as well as of interiority between humans and nonhumans belonging to the same totem. In his 1996 article, Descola broadened the scope of his comparison to include the three distinct modes of identification he calls animism, totemism, and naturalism. Descola also differentiates between distinct relational modes involving beings considered as persons; we thus find not only the predominant mode of predation, but also of relations of reciprocity and protection as possibilities for interactions between humans and nonhumans in animistic regimes.

The idea of perspectivism emerges in the context of Ingold's (I992) critique of Descola's notion of animism, which he considers to be sociocentric and incapable of overcoming the nature/culture binary. Viveiros de Castro - in an interesting twist - declares that, in contrast to other participants in the debate, such as Ingold and Descola, he wants to save the Lévi-Straussian opposition of nature and culture by showing that, in structuralist and relational terms, we are dealing with deictic and pronominal, rather than substantivist notions of nature and culture. That is why, according to Viveiros de Castro (I998: 474), both opponents and defenders of the nature/culture binary were wrong:

Ingold (I991; 1996) showed how schemes of analogical projection or social modelling of nature escape naturalist reductionism only to fall into a nature/culture dualism which by distinguishing 'really natural' nature from 'culturally constructed' nature reveals itself to be a typical cosmological antinomy faced with infinite regression. 
Viveiros de Castro, however, insists on the difference between humans and animals form the native point of view. His argument of symmetrical reversal becomes important here:

[...] if animism depends on the attribution of human cognitive and sensory faculties to animals [...], then what in the end is the difference between humans and animals? If animals are people, then why do they not see us as people?". [...] Finally, if animism is a way of objectifying nature in which the dualism of nature/culture does not hold, then what is to be done with the abundant indications regarding the centrality of this opposition to South American cosmologies? (Viveiros de Castro, I998: 474, emphasis added)

In this manner, if animism affirms a subjective and social continuity between humans and animals, its somatic complement, perspectivism, establishes an objective discontinuity, equally social, between live humans and dead humans (Viveiros de Castro, I998: 482-483).

It is the symmetrical and inverted relation between continuity and discontinuity in naturalist versus animist/perspectivist thought that enabled Viveiros de Castro to reinvent the nature/culture opposition for Amerindian and Western thought.

In my reading of this collaborative construction of a new model of thought, the disjunction between the continuity and discontinuity of body and soul that finds parallel in the opposition between animism and naturalism was the key to Descola's (2013) more ambitious model of four ontologies to account for all of the structurally possible ways humans relate to the world in Beyond nature and culture.

These four 'modes of identification', linked to modes of relating and conceptualizing the world, configure the four different ontologies that Descola calls 'naturalism', 'animism', 'totemism' and 'analogism'. Starting from the fact that some kind of distinction between interiority and physicality, body and soul, can be found in all thought traditions, Descola uses this opposition

as dimensions or axes along which humans may see themselves in continuity or discontinuity regarding nonhumans: if the interiority of nonhumans is similar to those of humans, but their physicality is not, we have animism; the inverse case gives us naturalism as similar physicalities combined with dissimilar interiorities; if the interiority and physicality of nonhumans are identical to those of humans, we have totemism; its inverse case is analogism, with dissimilar interiorities and dissimilar physicalities all the way down (Coelho de Souza, 20I4).

These modes of identification are polyvalent, universal dispositions that "come to have a public existence in the form of ontologies that favour one or another of them as the principle according to which the regime of existing beings is organized" (Descola, 2013: 247).

Despite this initial overlap of thought processes, the differences between Descola and Viveiros de Castro gradually became more evident. In his review of a debate between the two at the Collège de France in 2006, Latour typified 
these differences as a distinction between the 'type' and the 'bomb' (Latour, 2009). While Descola is working at refining his structuralist model to reduce the vast heterogeneity of ontologies past and present to a limited number of possible relations and figurations, Viveiros de Castro embarks upon a methodological critique of anthropological thought in general, twisting the LéviStraussian heritage into Deleuzian knots and planes that try to get as close as possible to the conceptual worlds of the otherwise.

These differences between Descola and Viveiros de Castro are neutralized again when they converge on the same structuralist or post-structuralist ground in contrast with other versions of the ontological turn, such as those that stress the phenomenological continuity between human and nonhuman processes of autopoesis and communication, lived and invented by animals and plants as well as by humans (e.g. Ingold, $20 \mathrm{II}$ ).

The need to think nature differently, as Gaia, a living being that has begun to react against its destruction by the anthropocene, brought together traditions with very different affiliations that have all been labelled as belonging to the 'ontological turn'. As Foucault once said, "perhaps one day this century will be known as Deleuzian" (Foucault, I970). Perhaps Deleuze's approach is in fact the only one able to produce an encounter between all these different lines of flight motivated by the otherwise, producing planes of contact between new materialism and structuralism, between post-humanism, object oriented theories and conceptual theories of immanence. There seems to be no clear definition of the ontological turn and hence no need to judge or decide who does and does not belong to it; all we have is this flight towards the future, situating us in-between the acknowledged equivocation of thought traditions of the otherwise and our own thought traditions, as these try to become open to the torsions and turnings made possible by the radicalization of an intellectual attitude that allows itself to become contaminated by Otherness, thus partially becoming other. ${ }^{\mathrm{I4}}$

It is my conviction that the only way to do this is by using the appropriate poetics, the appropriate aesthetics, because it is through aesthetics, song and 'twisted images' that the natives themselves deal with nonhumans. Equivocation is as crucial to the theory of knowledge professed by Amerindians as it is for anthropologists. One has to consider the space left uncovered by our efforts at translation, which remains open to experimentation. Once we enter the domain of aesthetics it is clear that the famous Batesonian framing of play and poetry becomes central: the play of suggesting without revealing, of equivocal images, visual puns (Bateson, 1955, 1972). This is the mind-set surrealist artists recognized in Amerindian art (Carpenter, I970; Gamboni, 2013; Lagrou, 2008). And Amerindians certainly do not confuse different states of being, since, as we will see, it would be fatal to perceive an image-being as an animal who takes the human himself to be the animal. 


\section{THE POETICS AND AESTHETICS OF OTHER BECOMING}

The Huni Kuin provide yet another turning to the symmetrical inversion of perspectives. As the Yudjá discussed above, they recognize a difference between having and being a spirit. Some animals are humans from their own point of view, which means that they have a 'soul', yuxin. But some animals are yuxin, 'spirit beings.' Yuxin are beings or perceptual phenomena marked by an ambiguity deriving from their capacity to transform. Encountered at dusk, always when the victim is alone, these yuxin announce their presence by mimicking the sound of animals. The hunter thinks he is following his prey, but he is actually becoming prey of an image-being, master of the transformation of form. An encounter with a yuxin is thus confirmed after the fact by its effects. The hunter feels very weak, faints or falls ill, barely managing to return home. In the worst case scenario, he does not return at all, and slowly starts to adopt the point of view, affects and physicality of the yuxin being who captured him.

Yuxin, image-beings, are responsible for most illnesses, which are caused by their attempts to capture human souls and lock them into new bodies, those once possessed by their animal doubles. They are particularly dangerous for young hunters who kill male animals, which then take revenge by means of their doubles, their yuxin. Different kinds of game produce nisun. Nisun is a dizziness and headache, and when it is particularly acute it can lead to fainting. Huni Kuin shamanism consists in actively seeking encounters with these yuxin beings and successfully counteracting the negative effects they have on human embodied souls when they remain unknown and invisible. To feel dizziness when under the effect of ayahuasca and tobacco is a first step in obtaining the knowledge of what the body spirit of an animal can do to one's eye-soul.

The Huni Kuin use what can be called 'perspectival plants'. When in liquid form, these plants can be used as eye drops or ingested. They change a human's perceptual world, allowing him or her to adopt the point of view of other beings. ${ }^{15}$ Yuxin do not need these perception shifters, for they control the forms to be seen. The master of all yuxin is Yube, the anaconda. He is the owner of the potent ayahuasca brew, considered to be his blood. Visionary experiences under the effects of the brew are important cosmopolitical events and can be described as real aesthetic battlefields where yuxin beings throw images, ornaments and designs onto the eye-soul of humans who enter their realm. The ritual singer responds through powerful 'song lines' that become lines of vision to be followed by the eye-souls of those who are in trouble. People take the brew in order to see. The following extract of a song shows the eye soul being covered in Yube's cloths: 


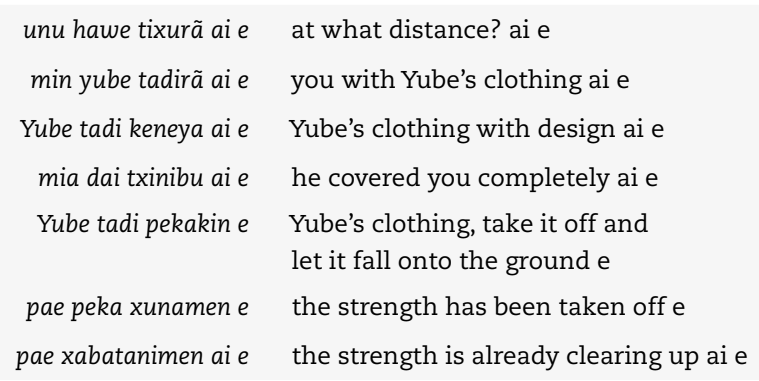

Another way of adopting the body and point of view of Yube is to be covered in his necklaces, as we can discern in the following extract of a 'calling song': the necklaces of Yube ee ia ee

the beads of Yube crossed over the chest ee ia ee he covered your chest completely ee ia ee let's remove the necklaces ee ia ee [comment by Leôncio, the owner of song: it was very beautiful. That's why you have to remove it to recover].

the vine nawa huni is letting loose ee ia ee the vine already dropped ee ia ee the vine is getting clear ee ia ee

The idea of an aesthetic battle is made explicit in the following song:

$$
\begin{gathered}
\text { himi miã newane ee ia ee } \\
\text { mia newã baxakin ee ia ee } \\
\text { baxa duna dunankin ee ia ee } \\
\text { min pae baxakin ee ia ee } \\
\text { pae baxaxunamen ee ia ee }
\end{gathered}
$$

The blood in you, everything colored, totally blue ee ia ee (blood= the vine)

I throw the big blue on you ee ia ee thrown, everything is striped, colored ee ia ee the vine throws (the colors) on you ee ia ee the vine has already thrown ee ia ee 
To see and to be seen depends on an eminently relational quality that is never given. What the Yanomami shaman Davi Kopenawa has said of the xapiri spirit-helpers also holds true for Yube, the anaconda spirit of the Huni Kuin, and his revelation of his world of image-beings: to see these image-beings it is necessary to first be seen by them. They look at you and thus become visible for you (Kopenawa \& Albert, 20Io). To see xapiri one needs to become one of them and see with their eyes. In the same way, to see Yube and his transformational world, you need to see through his eyes. It is therefore not enough to ingest his soul-substance, the visionary vine, index of his agency inside your body. Yube, the anaconda spirit, can decide not to look at you, not to show himself to you; to show only 'lies' or simply show you nothing at all. The process of anaconda-becoming, a condition for obtaining visionary capacities, is not evident at all - besides being a very risky enterprise.

To be devoured by Yube is at once intensely longed for, and terribly frightful. To sing with the power of the vine in your voice you have to engage in a process of other-becoming, animal-becoming and molecular-becoming that only song can make and unmake. The song evokes the process of being swallowed by Yube in his monstrous, frightening form; neither human nor animal, but a hairy, undefined hybrid being. To be reborn as Yube one has to be swallowed by Yube. Only those who have thus been devoured and regurgitated by Yube can become one with him, taking on the power to cause visions through song. Henceforth, when he sings, it is the voice of Yube, of all beings of the forest, that sings through him:

Yubebaun manikin ee ia ee, means: We, yubebaun are playing. Yube is we; we are taking the vine in the company of Yube. Yubebun means a lot of them (a multiplicity), we singing. Singing together with Yube you have to warn (avisar) Yube to take away the headache, to warn, we sing all the illness we have: I have a lot of illnesses, headache, my knee, my back, fainting, we eat deer, fish, crab, spider monkey, male peccary. All these are names. Yubebun is us singing (Leôncio Domingos Huni Kuin, 2007).

Yube is an androgynous being, master of the transformation of form, but also owner of all the patterned designs that exist on its skin. Among the Huni Kuin, women are experts in the art of creating design patterns through body painting, weaving and basketry, while men materialize design through song or, more recently, in figurative paintings on canvases and walls. At the start of my research one man explained to me that when you take the vine "you have to stay inside the design". This can be translated as staying inside the perceptive space covered with design, so as to not get lost in the spirit world. To see properly, one has to listen. Song lines and the lines of vision are intrinsically interwoven. This is explained in the following song line taken from a kaiati song, meant to help clear one's vision: 


$\begin{aligned} \text { miki pae meka ee ia ee } & \text { the vine is playing with you } \\ \text { huni nama kaiaxun ee ia ee } & \text { in the middle of the vine } \\ \text { hatun nai dewedi ee ia ee } & \text { their song from the sky comes singing } \\ \text { nai dewe keneya ee ia ee } & \text { their song with design } \\ \text { mane beidaxumen } & \text { singing he brings them }\end{aligned}$

[the vine comes from far away singing for the people to get better]

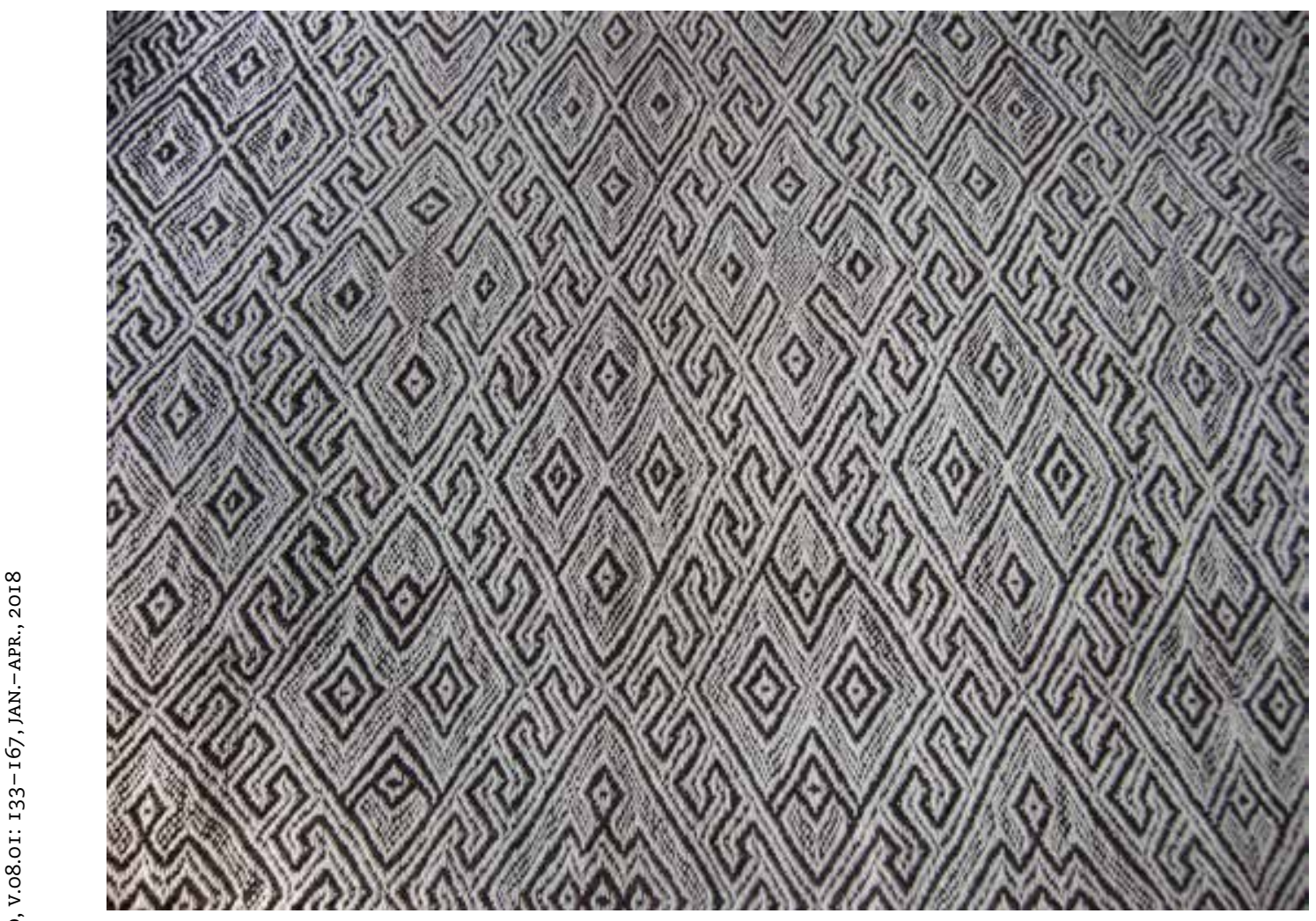

Detail from a Huni Kuin hammock with the dunuan kene, the anaconda design. 
You see the song as if being drawn; as a consequence the person can see and comes, he hears, this is for the person to feel better, if you hear this song things will clear up, I who sing feel better, the other who hears also gets better (Leôncio Domingos Huni Kuin, 2007).

The song, in other words, traces paths to be followed by the lost eye-soul of the person suffering. The eye-soul has to follow the design of the song as it unfolds before his eyes in order to be able to come back, to come close to the body of the one who sings, and hence to return to his own body. This is the reason why the master of song will lean against the shivering body of the one lost in the world of images, and sing in the plural voice of Yube, anaconda spirit, that we, I, you miss your body.

The vine connects the people by means of the song. It is in you who knows, (you) know where he goes, he knows that you know, because he has already swallowed you. (It is he who is singing in you with you). Goes to the other, it can be that (this one) is afraid. The path of the vine is also to walk between people. If I know how to sing, everybody will feel the way I sing. If the vine is my friend or my wife, I won't feel the effect strongly, but the other will scream (Sebidua, May 2015).

Let us now have a quick look at what the animal's body souls can do to human eye-souls. Below I present an extract from the song of the revenge of the peccary people, with translation and comments by Leoncio Domingos Huni Kuin, a renowned specialist.

xawã bani teskarãai a macaw's peach palm straw ai e

In the vine song this is how we call peccary's fur. Because, if one eats male peccary, one has to call this way, in order not to faint. You call peccary's fur and remove it. Palm straw. You were already wearing peccary cloth. Afterwards remove it, they are saying.

$$
\begin{array}{cl}
\text { ha kama puanã ai e } & \text { his big fur on his back ai e } \\
\text { tseka beirãxuma ai e } & \text { remove it, carrying ai e } \\
\text { bene siu pusinã ai e } & \text { testicle of male peccary, remove it from inside }
\end{array}
$$

In order not to become ill you have to remove all the poison of the peccary's substance in order not to faint.

$$
\begin{array}{cc}
\text { há tsius tameni ai e } & \text { it's stuck way inside ai e } \\
\text { tseka beirã xuma ai e } & \text { remove his penis ai e } \\
\text { xawã kuni henerã ai e } & \text { took macaw electric fish soup ai e } \\
\text { ha naxun apakin ai e } & \text { poured it here inside my belly ai e } \\
\text { pae bua kaia ai e } & \text { it is already taking its strength away }
\end{array}
$$

the electric fish gave a shock to the vine, who is withdrawing 
We are dealing with an aesthetic battlefield where the roles of prey and predator have been inverted in venatic and also in sexual terms. My teachers explained to me that in 'vine language' you never call the animal spirit or his owner by his everyday name. What we see is an imagistic description of what these doubles are doing to the person. It is as if the eye-soul got lost in a world of image-beings where it became trapped. The song, with its complex enunciator, at once we, he and you, is coming to the rescue. The eye-soul itself does not sing. The singer is thus the interpreter while the other is the perceiver. Huni Kuin ontology, as it is unveiled through the analysis of the huni ritual, reveals a theory of fractal personhood, where every unity is dual, every duality is a movement in-between, the dual becomes multiple and humanity partakes of all the levels of existence. The huni ritual consists of exploring the lines of flight of this constant process of other-becoming to their limits.

'Songs to see' thus take seriously the risk of literally becoming what one eats. That is, peccary-becoming, spider-monkey-becoming, vine-becoming, treebecoming, bird-becoming, virtual destinies made possible by the inversion of the predatory relation, when revenge is not averted. By contrast, jaguar-becoming and boa-becoming are actively sought by initiating shamans.

The shamanistic ritual of nixi pae clearly reveals the logics of an Amerindian ontology. Nixi pae is a mimetic, agonistic and highly aesthetic world in constant process of other-becoming: animal-becoming, women-becoming, childbecoming, plant-becoming, reptile-becoming and even molecular-becoming. If Deleuze and Guattari had had the chance to experience this world, they might not even have bothered to write Mil plateaus; the Huni Kuin had already done so in their nixi pae songs!

Because these songs involve complex and constant inversions of the positions of agent/patient, predator/prey, consumer/consumed, body/soul, human/animal, male/female and interior/exterior, the ontology underlying the world of nixi pae can be more properly called perspectivist than animist. But we could just as well invoke Lévi-Strauss's 'dualism in perpetual disequilibrium' (Lévi-Strauss, I99I). This dualism allows opposed and complementary Figures and Grounds to transform into each other, a characteristic of Huni Kuin graphic design and other Amazonian design systems, as I have explored at length elsewhere. This transformative capacity is responsible for the kinetic effect of figure and counter-figure that prevents the onlooker from fixing on a stable image (Lagrou, 20I Ib). The movement of other-becoming and of design, kene, systematically points toward the in-betweenness of all being, toward processes of becoming, of unfolding: in-between male and female, in-between lines and figures, in-between folding and unfolding.

All of this recalls a Klein bottle, mentioned by Lévi-Strauss in La potière jalouse (1985), where the interior unfolds into the exterior with no explicit rup- 
ture between the two. This logic is systematically processed in the songs of huni (the ritual name for the vine, meaning 'person'): one fold unfolds into another, there is a constant movement of inversion between inside and outside, between what was ingested and what ingests, the enunciator and the enunciated, producing a complex figure of unfolding, multiplication and other-becoming for the duration of the experience. ${ }^{16}$

We are here in the same shamanic universe where, as Taussig (I993) learned, to see and to know is to partially 'become other'. To my knowledge, Taussig was one of the first authors to associate vision with processes of otherbecoming, relying more on Walter Benjamin's optical unconscious and mimetic capacity than on the Deleuzian concept of becoming. The idea that the point of view is located in the body implies that vision is a tactile engagement withseeing and being seen. The eye touches and is encompassed by the surfaces it explores. To know and to see involve a far-reaching process of other-becoming (Taussig, I993).

Marilyn Strathern (2013) states that in Melanesia relations are made manifest through form. Forms, such as babies, yams and artefacts are the outcome of relations. Among the Huni Kuin, however, what is obviated through patterned form are relations themselves rather then their outcome: lines point toward the duality or multiplicity and in-betweenness of all being. The dual quality of personhood implies reversibility between different kinds of complementary relations: between the living and the dead, men and women, self and other, kin and stranger.

Pattern in western Amazonia registers movement, revealing an ontology of connectedness and the reversibility of all forms. Bodies are immersed in a constant process of becoming, of engendering and being engendered. The Waiãpi say that a shaman is connected to his auxiliary spirits by means of invisible lines (Gallois, I988). For the Huni Kuin, the lines that compose their designs are pathways to be followed by the eye-soul; they are the lines of song that form a soundscape, and one elderly lady told me that their design system, kene, is the language of the Yuxin beings (kene yuxinin hantxaki). The network of lines transmits waves and potencies, and is composed of paths to be followed by image-beings familiar to and perceived by those who are prepared for it. Similarly, for the Yudjá patterns on the skin are paths that connect the living to the dead, and this is the reason why one should not use design when mourning (Lima, I996).

Patterns reveal or suggest the multiple fractal relations that constitute and connect beings, persons and collectives. Persons in Amazonia are multiple and dual at different scales and this multiplicity is related to the contextual nature of selfhood and otherness. All agentive capacities for living are acquired through processes of partially incorporating and becoming other. Since the relation between pattern and surface is crucial - because all patterns adhere to skins, bodies, and 
other containers - something happens to design when the perceptual field changes, when the eyes that look upon it are no longer the same. The perception of design and its relation to song lines constitute an important part of the shamanistic experience with ayahuasca in Western Amazonia. For the Huni Kuin, Shipibo, Piro, Desana, Siona and other groups of the region, the visionary experience of seeing the world covered in design is a feature of the state of being intoxicated by the vine. For the Huni Kuin, to see the world this way is to see the world through the eyes of Yube/anaconda. The one intoxicated with the vine sees the world covered in its skin. That which has been swallowed - the potent substance, blood of Yube, the anaconda/ancestor (self and other), planted and transformed into vine - will swallow its 'predator' in turn. That which has been encompassed will encompass, and back again.

The line sets the transparency of the skin, the suspension of limits between bodies; it traces pathways and opens up toward the perception of Figures inside the frame of the patterned surface. ${ }^{17}$ Different formal characteristics found in Amazonian design systems constitute techniques for the focalization of the gaze. The kinaesthetic effect of switching between figure and ground causes the opacity of the surface to disappear and produces movement and changing levels of depth in perceptive space. The Figure thus seems to approach and recede in an alternating rhythm. This visual technique aligns with the highly transformative universe of Amazonian Multinaturalism that assumes 'variation as nature', as we saw above (Viveiros de Castro, 20I4). The engendering of pattern, as a spider spins its web while moving along the unfolding lines (Ingold, 20I I), follows the logic of variation, of small differences that make every actualization of pattern an act of invention.

\section{CONCLUSION}

I began this article by locating the widespread interest in Amerindian ethnology's ontological turn in the context of the urgent problems concerning the survival of the planet caused by the anthropocene. The need for a new relational (cosmo)politics, where humans and nonhumans are not opposed but interdependent, is partially responsible for this renewed interest in Amerindian ethnology by other disciplines and beyond academic circles. This situation is reminiscent of other historical moments when Amazonia also spoke to the imagination of the world as a source of alternative solutions for humanity.

In the subsequent section, I undertook a highly situated archaeology of the key concepts of the ontological turn and of how this discussion turns on the crucial question of the relation between the twin concepts of 'nature' and 'culture', and of how to overcome or redefine both relation and terms.

In the last section, I showed how our theories can be further refined and developed through very specific and precise ethnographic exegeses that takes native philosophical language seriously. As is well known to specialists, Amer- 
indian ontologies do not reveal themselves as systematized philosophical treaties. They are hidden, instead, behind the twisted images in the lyrics of their song, frequently considered to be the language of non-human beings, a language only comprehensible to specialists generally called 'shamans' or 'masters of song'. As Leach (2000) once said, to understand the ethics of a people one has to study their aesthetics. We could offer a contemporary version of this insight by substituting 'ontology' for 'ethics'. To understand the specific ontology of a people, one has to have access to the exegesis of its poetic Figures and Images, to the lines that reveal the hidden connections between beings and forms.

It is my conviction that we will only progress in understanding these complex ontologies if we take aesthetics seriously. We need in-depth studies of specific ontologies that can reveal the complexity and diversity of Indigenous thought, and can put us on the road to understanding 'alternative' as well as 'deep' ontologies. As an example of this approach, I have tried to show how the careful study and exegesis of Huni Kuin poetics, as revealed in shamanistic huni meka songs, is a privileged way of 'learning to see in Amazonia'. It allows us to discover an Amerindian relational aesthetics that emphasizes processes of change and becoming, where selfhood is systematically traversed by otherness, and where images point towards being in-between, as well as to the fact that every entity is fractal and can be split in two and many.

Received on 28/I I/20I7 | Revised on 7/2/20I8 | Approved on Io/2/20I8.

Els Lagrou is a professor in the Department of Anthropology at Federal University of Rio de Janeiro (UFRJ) and has published, among other books, A fluidez da forma: arte, alteridade e agência em uma sociedade amazônica (Kaxinawa, Acre) (2007). 


\section{NOTES}

I I want to thank Marilyn Ivy for the invitation and organization of the Seminar, and for the interesting discussion that followed. I also want to thank Marilyn Ivy and her colleagues at Columbia, especially Michael Taussig, Ana Ochoa, Partha Chatterjee, John Pemberton, Severin Morris Fowles, Brian Larkin, Myron Cohen, Brian Boyd, and others.

2 In a lecture at Cambridge in honour of the work of Marilyn Strathern, Viveiros de Castro (20I4b) traced the vast theoretical ramifications of the resurgence of the concept of 'ontology' in the anthropological literature and addressed some of the ensuing critiques. See also Pedersen (2012) for a response to critics, especially in the context of the British anthropological debate (Venkatesan et al., 20I0; Keane, 2009; Heywood, 2012, among others). In the United States, critiques of the ontological turn, in general, and perspectivism in particular, have been formulated by Terence Turner (2009) and Bessire \& Bond (20I4), among others.

3 Along with Donna Haraway, Dipesh Chakrabarty, Bruno Latour, Patrice Maniglier, Isabelle Stengers, and others, Elizabeth Povinelli was invited to the International Colloquium 'The Thousand Names of Gaia: From the Anthropocene to the Age of the Earth', organised by Viveiros de Castro, Bruno Latour and Deborah Danowski in Rio de Janeiro in September 2014.

4 Holbraad \& Pedersen (2017) distinguish those who emphasize the political potential and impact of taking other ontologies seriously, called the 'alternative ontology' (in the singular), from those who see the ontological turn in anthropology predominantly in terms of an intellectual attitude and methodology inspired by ethnographic experience, called 'deep ontologies' (in the plural). Although they admit it is very difficult to draw a line, authors such as Eduardo Kohn (2013), Marisol de la Cadena (2015) and Tim Ingold (20II) are classified among the first, while the authors situate themselves and their intellectual guides (Roy Wagner, Marilyn Strathern and Eduardo Viveiros de Castro) on the other side of the divide. 
5 In the following pages I cite Haraway and Povinelli from the interviews they gave at the conference. See the videos at the official site of the event: <https://thethousandnamesofgaia.wordpress.com>.

6 I borrow the concept of 'image-being' (être-image) from the translation for xapiri proposed by Davi Kopenawa and Bruce Albert (2010) for those beings, or doubles normally translated as spirits.

7 But see Luiz Costa and Carlos Fausto (2010), where they explore the affinities of the concepts of animism and perspectivism with the ethnological context of hunting societies, and address criticisms formulated with respect to these concepts from the conceptual fields of phenomenology and pragmatism.

8 La Boétie, Le Contr'un ou Discours de la servitude volontaire, I574, in Clastres (2004: II8). In Clastres' view, Montaigne and La Boétie were the only sixteenth century intellectuals to have thought against the grain, both allowing that primitive people constituted societies in the real sense of the word; societies, that is, without the celebrated division between those who obey and those who command (Clastres, 2004: I39).

9 "Decolonizing anthropology" was the title of a conference by Overing at the Biannual Meeting of Anthropology of the Mercosul (RAM) in 2003 (see Overing, 2004), as well as of a joint research project in place during the early I990s, including Viveiros de Castro and Overing with their respective students.

Io Alcida Rita Ramos (2012) wrote a critical article on the influence of 'perspectivism' on Brazilian ethnology, in which she affirms that "the model's generality has resulted in a remarkable similarity of ethnographic interpretations, giving the false impression that the Amazon is a homogeneous area" (Ramos, 20I 2: 48I). The authors she picks out for criticism are scathed for offering diminished copies of a dominant model. However, all of them are senior scholars who carried out their research before the formulation of the concept of perspectivism, and have, in this way, actively contributed to the empirical and theoretical advancement of the field that laid the groundwork for the concept's success. They cannot, therefore, be accused of passive repro- 
duction. The density and variety of the themes studied by these and other ethnographers in the wake of perspectivist theory furthermore constitutes the most eloquent possible answer to Ramos' (and others') verdict of a straightjacket imposed on Amerindian ethnology by a specific theory. This body of work shows that, although we may recognize a template, an ontological orientation that traverses the Amerindian cosmopolitical universe (one that had already been revealed by Lévi-Strauss in his Mythologiques), this recognition by no means impedes the proliferation of indepth studies of the multiple variations of central themes such as predation, nurture, alterity, the body and personhood. Ramos also claims that "the recurrent use of certain laden expressions can have adverse consequences for indigenous peoples". The recent history of political mobilization against the deleterious effects of the Anthropocene, however, seems to find in the concept of perspectivism a powerful tool for questioning the superiority of the ontology underpinning Late Capitalism's devastating relation with the earth's resources and inhabitants. Another of Ramos' critiques addresses the role and authorship of indigenous scholars that have until recently had little voice in Brazilian anthropology. Although this situation has been changing radically in the last few years, there remain, as yet, problems of mediation and asymmetry that need to be seriously examined, as convincingly argued by Oscar Calavia Sáez (20I4). For a very short answer to Ramos see my comment on Londoño (Lagrou, 20I7). For a theoretical defence of the ontological turn as method of thought see Viveiros de Castro (2014b) and Holbraad (2016).

I I See, for example, Goldman's focus on the relations between indigenous and afro-Brazilian collectives and on symmetrical anthropology (Goldman, 2015, 2016).

I2 Stolze Lima (I999a: 637) remembers she came up with the idea of 'point of view' because it offered an alternative, enabling her "to take a certain distance with respect to the ethnological problem of predation that was so important at the time for my colleagues and supervisor". "But", she concludes, "the notion that the ground is war, cannibalism, death and power, never abandoned me". For the importance of this encompassing ground of cosmological predation for 
the delineation of a precarious figure of freedom and peace conquered by human collectives, see Overing (I986b).

I3 See Strathern (1999) for an elaboration on the similarities and differences between her use of the concept of perspective in the Melanesian context and the concept of perspectivism proposed by Viveiros de Castro for Amerindian thought.

I4 For an attempt to do exactly this, to distinguish the different theoretical currents gathered under the name ontological turn, see Holbraad \& Pedersen (2016).

I5 See Déléage (2009) for the Sharanahua, neighbours of the Huni Kuin who also speak a Panoan language and use perception-altering plants, called plantes perspectives by the author. See also Gebhart-Sayer (1986) for the first mention of the use of perception altering eye-drops by the Shipibo.

I6 The figure of the bottle of Klein has also been used by Gow (200I) to describe the workings of visionary experience among the Piro.

I7 In his analysis of the work of Francis Bacon, the Logic of Sensation (I98I), Deleuze proposes the use of the concept of the 'Figure' instead of the figurative. His analysis of the lines of force that constitute an image, and the resulting Figure that is not a representation, is useful for our analysis of altered perception.

\section{BIBLIOGRAPHY}

Århem, Kay. (1996). The cosmic food web: human-nature relatedness in the Northwest Amazon. In: Descola, Philippe \& Pálsson, Gísli (eds.). Nature and society: anthropological perspectives. London: Routledge, p. I85-204.

Århem, Kay. (I990). Ecosofía Makuna. In: Correa, François (ed.). La selva humanizada: ecología alternativa en el trópico húmedo colombiano. Bogotá: Fondo Editorial CEREC, p. Io9-I26.

Bateson, Gregory. (1972). Style, grace and information in primitive art. In: Steps towards an Ecology of mind. Collected essays in anthropology, psychiatry, evolution, and epistemology. Chicago/London: University of Chicago Press, p. I28-I52. Bateson, Gregory. (1955). A theory about play and phantasy. Psychiatric Research Reports, 2, p. 39-5I. 
Bessire, Lucas \& Bond, David. (2014). Ontological anthropology and the deferral of critique. American Ethnologist, 4I/3, p. 440-456.

Boas, Franz. (1955) [1927]. Primitive art. New York: Dover Publications.

Bregalda, Damiana Jaenisch. (2017). Cosmocoreografias. Poéticas e políticas do mover. PhD Thesis. Universidade do Estado do Rio de Janeiro.

Carpenter, Edmund Snow. (I970) [I959]. Eskimo. Toronto: University of Toronto Press.

Clastres. Pierre. (2004) [1980]. Archeology of violence. Los Angeles: Semiotext(e).

Clastres. Pierre. (I989) [1974]. Society against the State: essays in political anthropology. New York: Zone books.

Clifford, James. (I988). The predicament of culture. Twentieth-century ethnography, literature, and art. Cambridge, MA/ London: Harvard University Press.

Clifford, James. (I98I). On ethnographic surrealism. Comparative studies in Society and History, 23/4, p. 539-564.

Conklin, Beth. (200I). Consuming grief. Compassionate cannibalism in an Amazonian society. Texas: University of Texas Press.

Coelho de Souza, Marcela. (2014). Descola's Beyond nature and culture, viewed from Central Brazil. HAU: Journal of Ethnographic Theory, 4/3, p. 419-429.

Costa, Luiz \& Fausto, Carlos. (2010). The Return of the Animists: Recent Studies of Amazonian Ontologies. Religion and Society, I/I, p. 89-I09.

Crocker, J. Christopher. (1977). My Brother the Perrot. In: Sapir, David J. \& Crocker, J. Christopher (eds.). The social use of metaphor: essays on the anthropology of rhetoric. Philadelphia: University of Pennsylvania Press, p.I64-I92.

De la Cadena, Marisol. (2015). Earth beings. Ecologies of practice across the Andean worlds. Durham/London: Duke University Press.

Déléage, Pierre. (2009). Le chant de l'anaconda. L'apprentissage du chamanisme chez les Sharanahua (Amazonie occidentale). Nanterre: Société d'ethnologie. 
Deleuze, Gilles. (2003) [I98I]. Francis Bacon, the logic of sensation. London: Continuum.

Deleuze, Gilles \& Guattari, Félix. (1987). A thousand plateaux. Capitalism and schizophrenia. Minneapolis: University of Minnesota Press.

Descola, Philippe. (2013) [2005]. Beyond nature and culture. Chicago: The University of Chicago Press.

Descola, Philippe. (2005). Par-delà nature et culture. Paris: Gallimard.

Descola, Philippe. (1996). Constructing natures: symbolic ecology and social practice. In: Descola, Philippe \& Pálsson, Gísli (eds.). Nature and society. Anthropological perspectives. London: Routledge, p. 93-II6.

Descola, Philippe. (1992). Societies of nature and the nature of society. In: Kuper, Adam (ed.). Conceptualizing society. London/New York: Routledge, p. I07-I26.

Descola, Philippe. (I986). La nature domestique. Symbolisme et praxis dans l'écologie des Ashuar. Paris: Editions de la maison des sciences de l'homme, I986.

Foucault, Michel. (1970). Theatrum philosophicum. Critique, 282, p. 885-908.

Gallois, Dominique Tilkin. (I988). O movimento na cosmologia Waiãpi: criação, expansão e transformação do mundo. $\mathrm{PhD}$ Thesis. PPGAS/Universidade de São Paulo.

Gamboni, Dario. (2013). Paul Gauguin au "centre mystérieux de la pensée". Paris: Les presses du reel.

Gebhart-Sayer, Angelica. (1986). Una terapia estética: los diseños visionarios del ayahuasca entre los Shipibo-Conibo. America Indígena, XLVI/I, p. I89-2I8.

Gell, Alfred. (1998). Art and agency. An anthropological theory. Oxford: Clarendon Press.

Goldman, Marcio. (2016). Mais alguma antropologia. Ensaios de geografia do pensamento antropológico. Rio de Janeiro: Ponteio.

Goldman, Marcio. (20I5). 'Quinhentos anos de contato': por uma etnografia etnográfica da (contra)mestiçagem. Mana, 2I/3, p. 64I-659.

Gonçalves, Marco Antonio. (200I). O mundo inacabado. Rio de Janeiro: Ed. UFRJ. 
Gray, Andrew. (1996). The Arakmbut of Amazonian Peru. Vol. I: Mythology, spirituality and history in an Amazonian community. Providence/Oxford: Berghahn Books.

Gow, Peter. (200I). An Amazonian myth and its history. Oxford: Oxford University Press.

Haraway, Donna. (2014). Tentacular Worldings in the Chthulucene. Videoconference. Available at <https://thethousandnamesofgaia.wordpress.com/>.Accessed I/I2/2017.

Henare, Amira; Holbraad, Martin \& Wastell, Sari (eds.). (2007). Thinking through things. Theorizing artifacts ethnographically. London: Routledge.

Heywood, Paolo. (2012). Anthropology and what there is: reflections on 'ontology'. Cambridge Anthropology, 30/I, p. I43I5I.

Holbraad, Martin. (2016). Three ontological turn-ons. Video. Available at <https://www.youtube.com/watch?v=cSQBe-V7Jw>. Accessed 18/2/2018.

Holbraad, Martin \& Pedersen, Morten Axel. (2017). The ontological turn: an anthropological exposition. Cambridge: Cambridge University Press.

Ingold, Tim. (20II). Being alive: essays on movement, knowledge and description. London: Routledge.

Ingold, Tim. (1992). Culture and perception of the environment. In: Croll, Elisabeth \& Parkin, David (eds.). Bush base: forest camp. Culture, environment and development. London: Routledge, p. 39-56.

Keane, Webb. (2009). On multiple ontologies and the temporality of things. Available at <http://www.materialworldblog.com/2009/07/on-multiple-ontologies-and-thetemporality-of-things/>. Accessed 24/II/20I7.

Kelly, José Antonio. (200I). Fractalidade e troca de perspectivas. Mana, 7/2, p. 95-132.

Kohn, Eduardo. (2013). How forests think: toward an anthropology beyond the human. London/Berkeley: University of California Press.

Kopenawa, Davi \& Albert, Bruce. (20ro). La chute du ciel. Paroles d'un chaman yanomami. Paris: Plon.

La Boétie. (1976). Le discours de la servitude volontaire. Paris: Payot. 
Lagrou, Els. (2017). Comment on 'Moral sources and the reproduction of the Amazonian package' by Carlos Londoño. Current Anthropology, 58/4, p. 477-50I.

Lagrou, Els. (2014) [2009]. Arte indígena no Brasil: agência, alteridade e relação. Belo Horizonte: C/Arte.

Lagrou, Els. (2013). Podem os grafismos ameríndios ser considerados quimeras abstratas? Uma reflexão sobre uma arte perspectivista. In: Lagrou, Els \& Severi, Carlo (eds.). Quimeras em diálogo: grafismo e figuração nas artes indígenas. Rio de Janeiro: 7Letras, p. 67-Iog.

Lagrou, Els. (20ria). Existiria uma arte das sociedades contra o Estado? Revista de Antropologia, 54/2, p. 747-780.

Lagrou, Els. (20IIb). Le graphisme sur les corps amérindiens. Des chimères abstraites? Gradhiva: Revue d'Anthropologie et d'Histoire des Arts, I3, p. 69-93.

Lagrou, Els. (2008). A arte do outro no surrealismo e hoje. Horizontes antropológicos, I4/29, p. 217-230.

Lagrou, Els. (1998). Cashinahua cosmovision: A perspectival approach to identity and alterity. PhD Thesis. CAS/University of St. Andrews.

Latour, Bruno. (2009). Perspectivism: Type or bomb? Anthropology Today, 25/2, p. I-2.

Latour, Bruno. (I99I). Nous n'avons jamais été modernes. Essay d'anthropologie symétrique. Paris: Éditions La Découverte.

Leach, Edmund. (2000) [1954]. Ritual as an expression of social status. In: Hugh-Jones, Steven \& Laidlaw, James (eds.). The essential Edmund Leach, vol. I. Guildford: Biddles, p. I53-I54. Lévi-Strauss, Claude. (I99I). Histoire de Lynx. Paris: Pocket. Lévi-Struass, Claude. (1985). La potière jalouse. Paris: Plon. Lima, Tânia Stolze. (I999a). Para uma distinção etnográfica da distinção natureza e cultura na cosmologia juruna. Revista Brasileira de Ciências Sociais. I4/40, p. 43-52.

Lima, Tânia Stolze. (I999b). The two and its many: reflections on perspectivism in a Tupi cosmology. Ethnos, 64/I, p. I07-I3I. Lima, Tânia Stolze. (I996). O dois e seu múltiplo: reflexões sobre o perspectivismo em uma cosmologia tupi. Mana, 2/2, p. 2I-47. 
Ochoa Gautier, Ana Maria. (2016). Acoustic multinaturalism, the value of nature, and the nature of Music in Ecomusicology. Boundary 2, 43/I, p. I07-I4I.

Overing, Joanna. (2004). A reação contra a descolonização da intelectualidade. Ilha, 6/I-2, p. 5-27.

Overing, Joanna. (I990). The shaman as a maker of worlds: Nelson Goodman in the Amazon. Man, New Series, 25/4, p. 6o2-6ig.

Overing, Joanna. (1989). The aesthetics of production: the sense of community among the Cubeo and Piaroa. Dialectical Anthropology, I4, p. I59-I75.

Overing, Joanna. (1986a). Men control women? The 'Catch 22' in the analysis of gender. International Journal of Moral and Social Studies, I/2, p. I35-I56.

Overing, Joanna. (I986b). Images of cannibalism, death and domination in a nonviolent society. Journal de la Société des Américanistes, LXXII, p. I33-I56.

Overing, Joanna. (1977). Orientation for Paper Topics. Comments: Social Time and Space in Lowland South American Societies. Actes du XLII Congrès International des Américanistes, 2, p. 9-10, p. 387-394.

Pedersen, Morten Axel. (2012). Common nonsense: a review of recent reviews of the ontological turn. Anthropology of this Century, 5. Available at <http://aotcpress.com/ articles/common_nonsense/>. Accessed I8/2/20I8.

Povinelli, Elizabeth. (20I6). Geontologies. A requiem to late Liberalism. Duke: Duke University Press.

Povinelli, Elizabeth. (20I4). As três figuras do antropoceno. Videoconference. Available at <https://thethousandnamesofgaia.wordpress.com/>. Accessed I/I2/2017.

Ramos, Alcida Rita. (20I2). The politics of perspectivism. Annual Review of Anthropology, 4I, p. 48I-494.

Sáez, Oscar Calavia. (2014). Do perspectivismo ameríndio ao índio real. Campos, I3/2, p. 7-23.

Sahlins, Marshall. (2013). Preface. In: Descola, Philippe. Beyond nature and culture. Chicago: The University of Chicago Press.

Sayre, Nathan. (2012). The politics of the Anthropocene. Annual Review of Anthropology, 4I, p. 5I-70. 
Stengers, Isabelle. (2010). Cosmopolitics I. Minneapolis: University of Minnesota Press.

Strathern, Marilyn. (2013). Learning to see in Melanesia. Lectures given in the Department of Social Anthropology at Cambridge University, I993-2008. Hau Books (Master Class Series 2). Available at <https://haubooks.org/learning-tosee-in-melanesia/>. Accessed 18/2/2018.

Strathern, Marilyn. (1999). Property, substance and effect: anthropological essays on persons and things. London: The Athlone Press.

Strathern, Marilyn. (1988). The Gender of the gift. London/ Berkeley: University of California Press.

Taussig, Michael. (1993). Mimesis and alterity. A particular history of the senses. New York/London: Routledge.

Taylor, Anne-Christine. (20II). Dom Quixote na América: Claude Lévi-Strauss e a antropologia americanista. Sociologia \& Antropologia, I/2, p. 77-90.

Turner, Terence. (2009). The crisis of late structuralism. Perspectivism and animism: rethinking culture, nature, spirit, and bodiliness. Tipiti: Journal of the Society for the Anthropology of Lowland South America, 7/I, p. I-42.

Venkatesan, Soumhya et al. (2010). Ontology is just another word for culture: motion tabled at the 2008 meeting of the Group for Debates in Anthropological Theory, University of Manchester. Critique of Anthropology, 30/2, p. I52-200.

Vilaça, Aparecida. (1992). Comendo como gente: formas de canibalismo wari. São Paulo/Rio de Janeiro: Anpocs/Ed. UFRJ.

Viveiros de Castro, Eduardo. (2014a) [2009]. Cannibal metaphysics. For a post-structural anthropology. Minneapolis: Univocal.

Viveiros de Castro, Eduardo. (2014b). Who is afraid of the ontological wolf? Some comments on an ongoing anthropological debate. CUSAS Annual Marilyn Strathern Lecture, 30 May. Viveiros de Castro, Eduardo. (2013). The relative native: essays on indigenous conceptual worlds. HAU: Journal of Ethnographic Theory, 3/3, p. 473-502.

Viveiros de Castro, Eduardo. (2012). Cosmological perspectivism in Amazonia and elsewhere. Masterclass Series I. Manchester: HAU Network of Ethnographic Theory. 
Viveiros de Castro, Eduardo. (2004). Perspectival anthropology and the method of controlled equivocation. Tipiti: Journal of the Society for the Anthropology of Lowland South America, 2/I, p. 3-22.

Viveiros de Castro, Eduardo. (1998). Cosmological deixis and Amerindian perspectivism: a view from Amazonia. Journal of the Royal Anthropological Institute, 4, p. 469-488.

Viveiros de Castro, Eduardo. (I996). Os pronomes cosmológicos e o perspectivismo ameríndio. Mana, 2/2, p. II5-I44.

Wagner, Roy. (I99I). The fractal person. In: Godelier, Maurice \& Strathern, Marilyn (eds.). Big men \& great men. Personifications of power in Melanesia. Cambridge: Cambridge University Press, p. I59-I73.

Wagner, Roy. (1975). The invention of culture. Chicago: The University of Chicago Press. 
Palavras-chave

Perspectivismo ameríndio; virada ontológica; etnologia; Antropoceno; estética relacional.

Keywords

Amerindian perspectivism; ontological turn;

Ethnology; Anthropocene; relational aesthetics.

\section{COPÉRNICO NA AMAZÔNIA: VIRADAS ONTOLÓGICAS PELA PERSPECTIVA DAS ETNOLOGIAS AMERÍNDIAS \\ Resumo}

Este artigo enfoca as contribuições teóricas da chamada virada ontológica ao debate antropológico. Para tanto situa inicialmente o interesse acadêmico despertado pelas ontologias ameríndias no contexto da crescente preocupação com consequências políticas do antropoceno. Empreende em seguida uma arqueologia do conceito de perspectivismo, central nos desdobramentos contemporâneos dessa vertente de estudos. Argumenta então em favor de um retorno à estética e à poética, entendidas como lugares privilegiados em que diferentes ontologias se manifestam. Tais instâncias emergem como decisivas para a percepção do caráter relacional das ontologias ameríndias. O argumento é sustentado por curta apresentação da estética huni kuin (kaxinawa) revelada no huni meka, canto da ayahuasca.

\section{COPERNICUS IN THE AMAZON: ONTOLOGICAL TURNINGS FROM THE PERSPECTIVE OF AMERINDIAN ETHNOLOGIES}

\section{Abstract}

In this article I explore the ontological turn in anthropological theory through three interconnected approaches. First, I situate the academic success of Amerindian ontologies in the context of recent debates on the urgency of addressing the political consequences of the anthropocene. Secondly, I undertake an archaeology of the concept of perspectivism as a central stage of the ontological turn, showing how the sub-discipline of Amerindian ethnology has always had a vocation for Copernican turnings, from the time of Montaigne until today. In conclusion, I argue for a return to aesthetics and poetics as the quintessential domains for exploring how different ontologies can teach us to look at the world differently. To understand the multiple versions of Amerindian relational ontologies we have to be able to perceive the relational character of the aesthetics they reveal. The argument is sustained by a short presentation of Huni Kuin (Cashinahua) aesthetics as revealed in huni meka, ayahuasca song. 